\title{
ROLE OF EDUCATION IN WOMEN ENTREPRENEURSHIP DEVELOPMENT IN NEPAL
}

\section{Minu Sigdel ${ }^{*}$}

\begin{abstract}
Men and women both experience personal problems during the startup of a business but women face more. This is especially true due to the lack of self-confidence and not being taken seriously by the fund providers when applying for funds. Relative to men, women tend to have lower access to land, education and training facilities. Thus, this study aims to study the ground realities of educational status of women entrepreneurs in the Kathmandu valley and to assesses the impact of education on their choice of business, their preferred legal ownership method, their means of obtaining funds and their means of getting support to initiate business.
\end{abstract}

\section{BACKGROUND}

Entrepreneurship refers to the act of setting up a new business or reviving an existing business so as to take advantage from new opportunity (Bhardwajet al., 2011). Cantillon (1735) describes an entrepreneur as a person who pays a certain price for a product to resell it at an uncertain price, thereby making decision about obtaining and using resources while consequently assuming the risks of enterprise. Similarly, women entrepreneurship is an act of business ownership and business creation that empowers women economically, increase their economic strength as well as position in the society (Despande, 2009). A women entrepreneur is an adult who owns and runs an enterprise, especially a commercial one, often at personal financial risks (Bhuvaneshwari, 2013).

Woman Entrepreneur is a person who accepts challenging role to meet her personal needs and become economically independent. A strong desire to do something positive is an inbuilt quality of entrepreneurial women, who is capable of contributing values in both family and social life. With the advent of media women are aware of their own traits, right and also the work situation (Rao, 2011).

Entrepreneurship is given significant importance due to its visible impact in wealth creation and employment generation. It has assumed super importance for accelerating economic growth both in developed and developing countries. It promotes capital formation and created wealth in the country. It reduces unemployment, poverty and is a pathway to a prosperous life (Bhardwaj, 2011).

\footnotetext{
Ms. Sigdel is Reader at Public Youth Campus, T.U., Kathmandu, Nepal
} 


\section{ROLE OF EDUCATION IN WOMEN...}

In Nepal women entrepreneurship is a new concept and has recently gained recognition. In developing countries like Nepal micro and small skill enterprise make major contributions in the development and most of the women are engaged in micro, cottage and small skill enterprises (MEDEP, 2007). One of the biggest hurdles that women entrepreneurs are facing in Nepal is the lack of access to proper education. In 1950 the literacy rates of men and women were 8.2 percent and 0.7 percent respectively. In 1991 literacy rate of men increased to 55 percent but women has risen only to 25 percent. In 2001 male literacy rate was 65.5 percent but female was 42.8 percent. In 2011 male literacy rate was 75.1 percent and female was 57.4 percent (Census 2011). This shows that literacy rate of women is rising however, this improvement in literacy rate have not made significant impact on women's life. In the male dominated society like ours, women are surrounded by many socio-personal obligations. From a very early age it is instilled into girl's mind that their most important duty is to assisting the mother in household activities (Ranabhat, 1995). Especially in rural areas, girls can get only primary education and thetare kept far from advance education. General mentality is that advance education is necessary only for male child (Ranabhat, 1995). Men have more chacesto start their own business and have more exposure for building their confidence. Women's role is only to support their male counterparts (Ranabhat, 1995). Women's opportunities are, therefore, limited within the household. Most of the women, especially in rural area, have high rate of illiteracy, less confidence, little knowledge of their legal rights and are confined to their responsibilities at home (Tuladhar, 1996). However, since 1985 various activities to promote the involvement of women in economic activities have been executed through various governmental and nongovernmental organizations. According to the statistical report of (DCSI, 2068/69), the total numbers of registered women entrepreneur in 75 districts was 10418. In 1995 government established a separate ministry for women development "Ministry of Women and Social Welfare" in order to improve the women's status in education, health, credit facilities and employment opportunities and also enable women to be economically independent. The women entrepreneurship and promotion programmes conducted are some of the significant steps of government and non-government level to make women capable and economically strong. Improvement after 1986, in the participation of women in economic activities, has shown that the number of women entrepreneurs has increased. The number of women employers too has increased and unemployed women are gradually decreasing in number (Shrestha, 2001). Most of the women are employed in informal sectors 
and low wage activities. Though women's participation in industrial activities is increasing, their work is limited mostly in knitting, tailoring, textile weaving, wool threading, tea processing and food processing (Pant, 2013).

\section{OBJECTIVE OF THE STUDY}

This study aimed at looking at the educational status of women entrepreneurs in the Kathmandu valley and see whether it has some impact on their choice of business, legal ownership status of business, means of obtaining funds and means of getting support.

\section{LITERATURE REVIEW}

Personal characteristics like age, education, family background, and training can have some influence in the choice of business, legal ownership status of business, means of obtaining funds and means of getting support. Some researchers have attempted to study the relationship between education and entrepreneurial success. According to Bates (1990), highly educated entrepreneurs were likely to create firms that remained in operation. Osirim (1990) cited similar results that high levels of educational attainment led to successful entrepreneurship.

A study done by Rajani and Sarada (2008) in Andhra Pradesh, India, found out that generally women think of business ideas in their thirties. During their thirties, women entrepreneurs think that they are capable of managing family and business. Most of the women entrepreneurs are married and they receive help from their husband. A study done by Sinha (2003) also supports this finding. Sinha (2003) revealed that majority of women entrepreneur seek guidance from their parents or husbands to start their business.

According to Bridge, O'Neill and Cromie (2003), although men and women both experience personal problems, women recorded more difficulties. This is especially true with regard to a lack of self-confidence and not being taken seriously by providers of funds when applying for funds (It is widely acknowledged that Indian women have access to fewer resources than men. For example, relative to men, they tend to have lower access to land, credit facilities, education and training facilities (KatepaKalala, 1999:7). Winn (2004) argued that the critical factors for women to succeed in independent businesses need to be understood to provide a better education and support system. Governments can provide female entrepreneurs with special loans, subsidies, funds, enterprise centers, entrepreneurship awards, counseling, training, advisory support, information products and web portals. Richardson, Haworth and Finnegan (2004) mentioned that women entrepreneurs suffer from significant 
material constraints and unhelpful attitudes arising from society's negative attitudes towards women in business.

Ghosh and Cheruvalath (2007) pointed out some of the challenges of women entrepreneurs covering a wide spectrum, including level of education, inter-role conflicts emanating from greater parenting responsibilities, a dearth of financial assistance and socio-cultural constraints.

Knowledge of latest technological changes, their know-how for business, and education level of the person are significant factors that affect business. The literacy rate of women in India is found at low level compared to male population. Many women in developing nations lack the education needed to spur successful entrepreneurship. They are ignorant of new technologies or unskilled in their use, and often unable to do research and gain the necessary training (UNIDO, 1995b: 1). Although great advances are being made in technology, many women's illiteracy, structural difficulties, and lack of access to technical training prevent the technology from being beneficial or even available to females ("Women Entrepreneurs in Poorest Countries," 2001).

\section{METHODOLOGY}

This study used primary and secondary data to support the analysis in different aspects. Primary data were collected through a set of questionnaire and interviews of women entrepreneurs. Hence, the study is based on describing and analyzing the issue. The primary data has been considered as the main basis of information. Secondary data are also used to support the primary data. The population of this research is registered members of women entrepreneurs within the DSCI, FNCCI, FWEAN, Nepal Chamber of Commerce, Trade Association etc. Primary data collected from the cottage, small and medium scale women entrepreneurs. The study covered only the women entrepreneurs of Kathmandu valley. The target group of this study is women entrepreneurs of micro, small and medium enterprises. The list of women entrepreneurs were categorized into different subgroups according to their business investment. Data has been processed in the computer using SPSS. Most of the variables have been presented in bi-variate table. Frequencies of response with their relative percentage, missing system, valid percentage as well as their cumulative percentage were computed along with the mean value. Chi-square values were also computed to check the associations and differences among variables.

\section{RESULTS AND DISCUSSION}

Table 1 below shows us the education level of our respondent women entrepreneurs. The academic qualification was divided into five categories, just literate, SLC, Intermediate, Bachelor, Master and above. 
Table 1: Academic Qualification of the Respondents

\begin{tabular}{|c|c|c|}
\hline Education Level & Frequency & Percent (\%) \\
\hline Just literate & 10 & 2.70 \\
\hline SLC pass & 65 & 17.70 \\
\hline Intermediate pass & 137 & 37.20 \\
\hline Bachelor pass & 111 & 30.20 \\
\hline Master and above pass & 45 & 12.20 \\
\hline Total: & 368 & 100.00 \\
\hline
\end{tabular}

Among the 368 respondents, 10 respondents were just literate, 65 respondents have studied up to SLC, 137 respondents had qualification equivalent to Intermediate $(+2), 111$ respondents had academic qualification of Bachelors and 45 respondents possess Master's and above. So, the sample contains 2.7 percent respondents just literate, 17.7 percent respondents having SLC, 37.2 percent respondents having Intermediate, 30.2 percent having bachelors degree and 12.2 percent have master degree and above.

\section{INFLUENCES OF EDUCATION ON TYPE OF VENTURES UNDERTAKEN}

Based on the education level of the women entrepreneurs, this study wanted to examine if education played any significant role in the type of venture undertaken by women entrepreneurs. The types of business venture were divided into manufacturing, trading, service and others. Around 72 percent of the respondents were involved in manufacturing business, 12 percent in trading and 11 percent in service. Table 2 presents the academic qualification of the women entrepreneurs with respect to the type of business they operate.

Table 2: Academic Qualification and Type of Venture

\begin{tabular}{|l|l|c|c|c|c|c|}
\hline & & \multicolumn{4}{|c|}{ Business Type } & \multirow{2}{*}{ Total } \\
\hline \multirow{3}{*}{\begin{tabular}{|l|c|c|c|c|} 
Education \\
Status
\end{tabular}} & $\begin{array}{c}\text { Manu- } \\
\text { facturing }\end{array}$ & Trading & Service & Other & \\
\cline { 2 - 6 } & Just literate & $70.0 \%$ & - & $30.0 \%$ & & $100.0 \%$ \\
\cline { 2 - 6 } & SLC pass & $72.3 \%$ & $6.2 \%$ & $13.8 \%$ & $7.7 \%$ & $100.0 \%$ \\
\cline { 2 - 6 } & $\begin{array}{l}\text { Intermediate } \\
\text { pass }\end{array}$ & $70.8 \%$ & $16.8 \%$ & $10.9 \%$ & $1.5 \%$ & $100.0 \%$ \\
\cline { 2 - 6 } & $\begin{array}{l}\text { Bachelor } \\
\text { pass }\end{array}$ & $76.6 \%$ & $9.9 \%$ & $9.0 \%$ & $4.5 \%$ & $100.0 \%$ \\
\cline { 2 - 6 } & $\begin{array}{l}\text { Master and } \\
\text { above pass }\end{array}$ & $71.1 \%$ & $13.3 \%$ & $11.1 \%$ & $4.4 \%$ & $100.0 \%$ \\
\hline
\end{tabular}


It can be seen in table 2 that irrespective of education level, most women are involved in manufacturing business. It can also be seen that women entrepreneur who have intermediate degree are greater in number followed by bachelor's degree. To test if there is an association between academic qualification and type of venture a Chi-square test was performed at5 percent margin of error. In the test, null hypothesis was "academic qualification and type of venture are independent of each other" whereas the Alternative hypothesis was academic qualification and type of venture are related. Below is the result of the test.

Table 3: Relationship between education level and type of business

\begin{tabular}{|l|c|c|c|}
\hline \multicolumn{3}{|c|}{ Chi-Square Tests } \\
\hline & Value & df & $\begin{array}{c}\text { Asymp. } \\
\text { Sig. (2- } \\
\text { sided) }\end{array}$ \\
\hline Pearson Chi-Square & $15.574^{\mathrm{a}}$ & 12 & .212 \\
\hline Likelihood Ratio & 16.351 & 12 & .176 \\
\hline $\begin{array}{l}\text { Linear-by-Linear } \\
\text { Association }\end{array}$ & .623 & 1 & .430 \\
\hline N of Valid Cases & 368 & & \\
\hline
\end{tabular}

The calculated chi-square value of 15.574 and $P$ value of .212 is compared with table value that fails to reject the null hypothesis. There is not enough evidence to prove that academic qualification and type of venture are dependent to each other. It can be said that education level does not determine the type of business women entrepreneur get involved in. It cannot be said that educated women get involved in certain type of business and non-educated women get involved in some other type. It can depend on various factors like personnel experience, personnel preferences, marker situation etc. However, many researchers have shown that highly educated entrepreneurs were likely to create firms that remained in operation (Bates (1990). Osirim (1990) cited similar results that high levels of educational attainment led to successful entrepreneurship.

INFLUENCES OF EDUCATION ON LEGAL OWNERSHIP STATUS OF BUSINESS

Type of business operated by women entrepreneur like sole ownership, partnership, corporation etc. can be influenced by academic qualification of the entrepreneur. Around 62 percent of respondents were involved in sole proprietorship, 26 percent in partnership and 10.6 percent in cooperatives. Following table (Table 3 ) breaks down the education level with respect to legal ownership status of business. 
Table 3: Education and Legal Ownership Status of Business

\begin{tabular}{|c|c|c|c|c|c|c|}
\hline & & \multicolumn{4}{|c|}{ Legal Ownership of Business } & \multirow[b]{2}{*}{ Total } \\
\hline & & $\begin{array}{l}\text { Sole } \\
\text { Owner- } \\
\text { ship }\end{array}$ & Partnership & $\begin{array}{c}\mathrm{Co}- \\
\text { operatives }\end{array}$ & Others & \\
\hline \multirow{5}{*}{$\begin{array}{l}\text { Education } \\
\text { Status }\end{array}$} & Just literate & $30.0 \%$ & $40.0 \%$ & $30.0 \%$ & & $100.0 \%$ \\
\hline & SLC pass & $72.3 \%$ & $21.5 \%$ & $4.6 \%$ & $1.5 \%$ & $100.0 \%$ \\
\hline & $\begin{array}{l}\text { Intermediate } \\
\text { pass }\end{array}$ & $59.9 \%$ & $29.9 \%$ & $9.5 \%$ & $.7 \%$ & $100.0 \%$ \\
\hline & $\begin{array}{l}\text { Bachelor } \\
\text { pass }\end{array}$ & $64.9 \%$ & $19.8 \%$ & $13.5 \%$ & $1.8 \%$ & $100.0 \%$ \\
\hline & $\begin{array}{l}\text { Master and } \\
\text { above pass }\end{array}$ & $55.6 \%$ & $33.3 \%$ & $11.1 \%$ & & $100.0 \%$ \\
\hline \multicolumn{2}{|c|}{ Total: } & $62.2 \%$ & $26.1 \%$ & $10.6 \%$ & $1.1 \%$ & $100.0 \%$ \\
\hline
\end{tabular}

Table 3 shows no association between academic qualification and legal ownership status of the business. Any clear indication that educated women prefer certain legal ownership over other cannot be seen. Most women prefer sole ownership irrespective of academic qualification. Basu, (2004) asserts that even if education qualification are not directly relevant to the business, they may contribute to growth in other ways, for example by improving the entrepreneurs communication skills with the majority community, including banks, which may in turn help to lift external financial resources constraints and low barrier to business development.

\section{Null Hypothesis}

Academic qualification and legal ownership status of business are independent of each other

Alternative Hypothesis

Academic qualification and legal ownership status are related

\begin{tabular}{|l|c|c|c|}
\hline \multicolumn{4}{|c|}{ Chi-Square Tests } \\
\hline & Value & df & $\begin{array}{c}\text { Asymp. Sig. } \\
\text { (2-sided) }\end{array}$ \\
\hline Pearson Chi-Square & $16.119^{\mathrm{a}}$ & 12 & .186 \\
\hline Likelihood Ratio & 16.305 & 12 & .178 \\
\hline $\begin{array}{l}\text { Linear-by-Linear } \\
\text { Association }\end{array}$ & .214 & 1 & .644 \\
\hline N of Valid Cases & 368 & & \\
\hline
\end{tabular}

Chi square analysis got a Chi-square value of 16.119 and a $\mathrm{P}$ value of 186. Since 186 are greater than alpha value of .05 , research fails to reject the null hypothesis. Academic qualification and legal ownership 
of business are independent of each other. Education level does not determine the legal ownership status of business.

\section{INFLUENCES OF EDUCATION ON SOURCE OF STARTUP FUND}

Startup fund is very important for any business. This research wanted to find out if education played certain role in procuring startup fund. It might be possible that highly educated women entrepreneur might get startup fund form sources that uneducated person do not normally get from. Following table (Table 4) breaks down the data based on education and source of startup fund.

Table 4: Education and Source of Startup Fund

\begin{tabular}{|c|c|c|c|c|c|c|c|}
\hline \multicolumn{7}{|c|}{ Source of Startup Fund } & \multirow[b]{2}{*}{ Total } \\
\hline & & $\begin{array}{c}\text { Personal } \\
\text { Saving }\end{array}$ & $\begin{array}{c}\text { House- } \\
\text { hold }\end{array}$ & $\begin{array}{c}\text { Borro- } \\
\text { wed } \\
\text { from } \\
\text { Rela- } \\
\text { tives or } \\
\text { Friends }\end{array}$ & $\begin{array}{c}\text { Financial } \\
\text { insti- } \\
\text { tutions }\end{array}$ & Others & \\
\hline \multirow[t]{5}{*}{$\begin{array}{l}\text { Education } \\
\text { Status }\end{array}$} & $\begin{array}{l}\text { Just } \\
\text { literate }\end{array}$ & $20.0 \%$ & $10.0 \%$ & $60.0 \%$ & $10.0 \%$ & & $100.0 \%$ \\
\hline & $\begin{array}{l}\text { SLC } \\
\text { pass }\end{array}$ & $13.8 \%$ & $33.8 \%$ & $23.1 \%$ & $27.7 \%$ & $1.5 \%$ & $100.0 \%$ \\
\hline & $\begin{array}{l}\text { Inter- } \\
\text { mediate } \\
\text { pass }\end{array}$ & $16.8 \%$ & $27.0 \%$ & $43.8 \%$ & $11.7 \%$ & $.7 \%$ & $100.0 \%$ \\
\hline & $\begin{array}{l}\text { Bachelor } \\
\text { pass }\end{array}$ & $13.5 \%$ & $32.4 \%$ & $32.4 \%$ & $19.8 \%$ & $1.8 \%$ & $100.0 \%$ \\
\hline & $\begin{array}{l}\text { Master } \\
\text { and } \\
\text { above } \\
\text { pass }\end{array}$ & $17.8 \%$ & $35.6 \%$ & $37.8 \%$ & $8.9 \%$ & & $100.0 \%$ \\
\hline \multicolumn{2}{|c|}{ Total: } & $15.5 \%$ & $30.4 \%$ & $36.4 \%$ & $16.6 \%$ & $1.1 \%$ & $100.0 \%$ \\
\hline
\end{tabular}

Above table suggests that most women use either household money (around 30\%) or borrow from relatives and friends (around 36\%) to start business irrespective of education level. Very few people use financial institutions to get their funds. One reason for it may be because financial institution process can be very confusing, there schemes can be difficult to understand and there is a fear that if you do not pay the bank then you can lose everything including your land and house.

\section{Null Hypothesis}

Academic qualification and source of startup fund of business are independent of each other

\section{Alternative Hypothesis}

Academic qualification and source of startup fund are related 


\begin{tabular}{|l|c|c|c|}
\hline \multicolumn{4}{|c|}{ Chi-Square Tests } \\
\hline & Value & df & $\begin{array}{c}\text { Asymp. Sig. } \\
\text { (2-sided) }\end{array}$ \\
\hline Pearson Chi-Square & $18.502^{\mathrm{a}}$ & 16 & .295 \\
\hline Likelihood Ratio & 19.375 & 16 & .250 \\
\hline $\begin{array}{l}\text { Linear-by-Linear } \\
\text { Association }\end{array}$ & .200 & 1 & .655 \\
\hline N of Valid Cases & 368 & & \\
\hline
\end{tabular}

Chi square analysis gives a Chi-square value of 18.502 and a $P$ value of .295 . Since .295 is greater than alpha value of .05 , thus, fail to reject the null hypothesis. Academic qualifications and source of startup fund are independent of each other. Education level does not determine the source of startup fund.

INFLUENCES OF EDUCATION ON SUPPORT TO INITIATE BUSINESS

Every entrepreneur requires support to initiate business and the study has shown that most of the women entrepreneurs interviewed were married and got support from there husband (around 56\%). In order to access if education played a role in determining the business initiation support from family member, statistical test was done. Table 5 breaks down the data by education level and support received by women entrepreneur to start their business.

Table 5: Education and Support to Initiate Business

\begin{tabular}{|c|c|c|c|c|c|c|c|c|}
\hline & & \multicolumn{6}{|c|}{ Support to Initiate Business } & \multirow[t]{2}{*}{ Total } \\
\hline & & $\begin{array}{l}\text { Hus- } \\
\text { band }\end{array}$ & $\begin{array}{l}\text { Father/ } \\
\text { Mother }\end{array}$ & $\begin{array}{l}\text { Fa- } \\
\text { ther in } \\
\text { Laws/ } \\
\text { Mo- } \\
\text { ther in } \\
\text { Laws }\end{array}$ & $\begin{array}{c}\text { Brother/ } \\
\text { Sisters }\end{array}$ & $\begin{array}{l}\text { Other } \\
\text { Rela- } \\
\text { tives }\end{array}$ & Friends & \\
\hline \multirow[t]{5}{*}{$\begin{array}{l}\text { Education } \\
\text { Status }\end{array}$} & $\begin{array}{l}\text { Just } \\
\text { literate }\end{array}$ & $40.0 \%$ & $30.0 \%$ & & $10.0 \%$ & $10.0 \%$ & $10.0 \%$ & $100.0 \%$ \\
\hline & SLC pass & $52.3 \%$ & $16.9 \%$ & $6.2 \%$ & $4.6 \%$ & $3.1 \%$ & $16.9 \%$ & $100.0 \%$ \\
\hline & $\begin{array}{l}\text { Inter- } \\
\text { mediate } \\
\text { pass }\end{array}$ & $56.9 \%$ & $23.4 \%$ & & $8.8 \%$ & $.7 \%$ & $10.2 \%$ & $100.0 \%$ \\
\hline & $\begin{array}{l}\text { Bachelor } \\
\text { pass }\end{array}$ & $55.9 \%$ & $22.5 \%$ & $1.8 \%$ & $7.2 \%$ & & $12.6 \%$ & $100.0 \%$ \\
\hline & $\begin{array}{l}\text { Master } \\
\text { and } \\
\text { above } \\
\text { pass }\end{array}$ & $62.2 \%$ & $24.4 \%$ & & $8.9 \%$ & & $4.4 \%$ & $100.0 \%$ \\
\hline \multicolumn{2}{|c|}{ Total: } & $56.0 \%$ & $22.3 \%$ & $1.6 \%$ & $7.6 \%$ & $1.1 \%$ & $11.4 \%$ & $100.0 \%$ \\
\hline
\end{tabular}


Husband played an important role in helping women entrepreneur to start their business. A Chi-square test was done to determine if education and support were dependent or independent of each other.

Null Hypothesis

Academic qualification and support to initiate business are independent of each other

Alternative Hypothesis

Academic qualification and support to initiate business are related

\begin{tabular}{|l|c|c|c|}
\hline \multicolumn{4}{|c|}{ Chi-Square Tests } \\
\hline & Value & df & $\begin{array}{c}\text { Asymp. Sig. } \\
\text { (2-sided) }\end{array}$ \\
\hline Pearson Chi-Square & $30.235^{\mathrm{a}}$ & 20 & .066 \\
\hline Likelihood Ratio & 26.778 & 20 & .142 \\
\hline $\begin{array}{l}\text { Linear-by-Linear } \\
\text { Association }\end{array}$ & 3.497 & 1 & .061 \\
\hline N of Valid Cases & 368 & & \\
\hline
\end{tabular}

Chi square test gave a Chi-square value of 30.235 and a $P$ value of .066. Since .066 is greater than alpha value of .05 , research fails to reject the null hypothesis. Academic qualification and support to initiate business are independent of each other. Education level does not determine the support received by women entrepreneur from their family and friend. It might help to ensure some additional confidence in people around if a women entrepreneur is educated but they receive equal amount of support irrespective of education. We can see most women are supported by husband. It could be because a wife working could be more income and more opportunity for the family as a whole.

\section{CONCLUSION}

Based on the education level of the women entrepreneur, this study wanted to examine if education played any significant role in the type of venture undertaken by women entrepreneurs, legal ownership of business, source of startup fund and support to initiate business. The study found that education level does not determine the type of business women entrepreneurs get involved in. It cannot be said that educated women get involved in certain type of business and non-educated women get involved in some other type. Also, education level does not determine the legal ownership status of business i.e. irrespective of education level most women entrepreneurs are involved in sole proprietorship business. Education level also has no effect on the source of startup fund to start the business by women entrepreneur. Irrespective of level of education most women entrepreneur borrows from friends or relatives rather than form banks or other financial institution. Also, level of education does not have any influence on the support received by 
women entrepreneur to start the business. It might help to ensure some additional confidence in people around if a women entrepreneur is educated but they receive equal amount of support irrespective of their education level.

\section{WORKS CITED}

Bhardwaj, G.N., Parashar, S., Pandey and B., Sahu, P. (2011). "Women Entrepreneurship in India: Opportunity and Challenges."CHIMC. Vol. 2, issue 7.

Bhuvaneshwari, P. and Annapoorani (2013). "Prospects and Challenges of Women Entrepreneurship with Specific Reference to Dalits."International Journal of Research in Commerce and Management. Vol. 4, issue 1/January.

Bridge, Simon, O’Neill, Ken and Cromie, Stan (2003). Understanding Enterprise, Entrepreneurship and Small Business. Basingstoke: Palgrave Macmillan.

Cantillon, Richard (1959). Essai Sur la Nature du Commerce in General (Essay on the Nature of Trade in General). Henry Higgs, ed. And trans.

Deshpande, S. and Sethi S.(2009). "Women Entrepreneurship in India (Problems, Solutions and Future Prospects of Development), Shodh, Samikshaaur Mulyankan."International Research Journal. Vol. 2, issue-9-10.

Ghosh, P. and Cheruvalath, R. (2007). "Indian Female Entrepreneurs as Catalysts for Economic Growth and Development."The International Journal of Entrepreneurship and Innovations. Vol. 8, (2): 139-148.

Katepa-Kalala P. (1999). Assessment Report on: Women and Poverty and Economic Empowerment of Women. Retrieved from $\mathrm{http} / / / \mathrm{www}$. uneca.org/eca_resorces/publication/women.

MEDEP report, 2007

Osirimi, Mary J. (1990). Characteristics of Entrepreneurship in Nigerian Industry that Started Small. Ph.D. Thesis, Harvard University, p. 25.

Pant, Sushil Kumar (2013). Socio-Cultural influence in Entrepreneurship Development in Nepal. Ph.D. Thesis, Faculty of Management, Tribhuvan University, Kathmandu.

Rajani, N. and Sarada, D. (2008). "Women Entrepreneurship and Support System."Stud Home Comm Sci. 2(2): 107-11.

Ranabhat, B.R. (1995). Women Entrepreneurs in Nepal: Their Profile, Problems and Prospects. Kathmandu: Small Business Promotion Project. 
Rao, J. Edukondala (2011). "Women Building Business in a Man's World. The Saga of Women Entrepreneurship."International Journal of Research in Computer Application and Management. Volume No. 2, Issue No. 1 (March).

Richardson, P. Howarth, R. and Finnegan (2004). The Challenges of Growing Small Businesses: Insights from Women Entrepreneurs in Africa, SEED Working Paper No. 47.

Shrestha, Binod K. (2001).Entrepreneurship Development: Issues and Opportunity. Bishwa Keshar Maskay (ed.) in Small and Medium Enterprises Development in Nepal, Kathmandu: Nepal, Center for Development and Governance.

Sinha, P. (2003). "Women Entrepreneurship in the North East India: Motivation, Social Support and Constraints."Indian Journal of Industrial Relations. 38 (4):425-443.

Tuladhar, Jyoti (1996). Factors Affecting Women Entrepreneurship in Small and Cottage Industries in Nepal. A Study of ILO and Sidu. UNIDO Annual Report, 1995.

Winn, J. (2004). "Entrepreneurship: Not an Easy Path to Top Management for Women."Women in Management Review. 19(3):143-153. 